\title{
ANALISIS PERBANDINGAN KONSEP KEBERFUNGSIAN SOSIAL DALAM PENGENTASAN KEMISKINAN NELAYAN DI WILAYAH PESISIR
}

\author{
Oleh \\ TINTIN FEBRIANTI \\ Fakultas Pertanian Universitas Garut \\ Email: tin2fb@gmail.com
}

\begin{abstract}
Abstrak
Berbagai pendekatan teoritis kemiskinan seringkali memandang kemiskinan sebagai kondisi dengan berbagai indikator "ketiadaan" seperti tidak memiliki pendapatan dengan jumlah tertentu, tidak memiliki rumah dengan kriteria tertentu, tidak memiliki akses terhadap pendidikan dan kesehatan dan sebagainya. Dalam realitas, orang miskin seringkali berjuang melawan kemiskinan dengan mengoptimalkan segala yang mereka miliki dan selama ini hal tersebutlah yang membuat mereka bertahan dari serangan kemiskinan tersebut. Dalam paradigm keberfungsian sosial, orang miskin memiliki berbagai sumberdaya (assets) baik aset finansial, aset sosial, aset fisik serta aset keluarga. Dengan berbagai kepemilikan aset tersebut, mereka mencari berbagai strategi coping supaya kehidupan mereka berkelanjutan. Berbagai paradigma dalam memandang kemiskinan tersebut akan menjadi dasar dalam berbagai program pengentasan kemiskinan. Tulisan ini bermaksud membandingkan berbagai paradigma dalam memandang kemiskinan tersebut yaitu paradigma neo liberal, paradigma demokrasi sosial serta paradigm keberfungsian sosial.
\end{abstract}

Kata kunci: kemiskinan, keberfungsian sosial, aset sosial, aset finansial, aset fisik, keluarga

\section{PENDAHULUAN}

Kemiskinan merupakan fenomena klasik dan lama yang sampai kini masih terjadi dan masih saja terus diperbincangkan akar masalah penyebabnya serta solusi penanggulangannya. Todaro (1998) menyajikan sebuah gambaran mengenai cakupan kemiskinan absolut (proporsi penduduk di suatu negara yang harus hidup di bawah garis kemiskinan internasional). Pada awal tahun 1990-an terdapat sekitar 1,25 miliar jiwa atau 23 persen dari total penduduk dunia yang harus hidup dalam kemiskinan absolut. Upaya pembangunan kiranya belum berhasil membawa masyarakat secara keseluruhan pada kondisi sejahtera. Tidak mengherankan jika salah satu poin dalam Millenium Development Goals (MDGs) yang ingin dicapai pada tahun 2015 adalah mengurangi proporsi penduduk yang hidup dalam kemiskinan dan kelaparan, "eradicate extreme poverty and hunger".

Begitu pun dengan Indonesia. Sebagai negara berkembang, Indonesia masih dihadapkan pada peliknya permasalahan ini. Dalam Laporan Perkembangan Triwulanan Perekonomian Indonesia pada tanggal 1 Maret 2013 dinyatakan bahwa tingkat kemiskinan terus menurun dengan lambat, menjadi 11,7 persen pada bulan September 2012, turun dari 12,5 persen pada tahun 2011. Namun tingkat kerentanan masih tetap tinggi, dengan hampir
40 persen dari penduduk hidup dengan tingkat konsumsi di bawah 1,5 kali garis kemiskinan nasional. Tingkat kemiskinan harus diturunkan secara lebih cepat agar Pemerintah dapat mencapai sasaran pengentasan kemiskinannya (sesuai definisi resmi pemerintah) menjadi 8-10 persen pada tahun 2014. Perlambatan dalam pertumbuhan PDB nominal seperti disinggung di atas, bersamaan dengan melemahnya Rupiah, juga telah menurunkan peningkatan bila diukur dalam kurs dolar AS sekarang. Menurut angkaangka BPS, PDB per kapita pada tahun 2012 adalah 3.563 dolar AS, meningkat hanya sebesar 1,8 persen dari 3.498 dolar AS pada tahun 2011 ketika laju pertumbuhan mencapai 17,5 persen. (World Bank, 2014).

Bertitik tolak dari data- data sekunder tersebut, bisa saja terjadi kenyataan di lapangan melebihi data yang ada, karena jika kita berbicara tentang kemiskinan maka wujudnya lebih tepat diibaratkan sebagai fenomena gunung es atau kerbau mandi di sungai, maksudnya terlihat kecil di permukaan namun jika diteliti lebih dalam makin ke bawah makin ke dasar akan terlihat makin membesar. Begitu pun dengan kemiskinan, tergantung terhadap indikator kemiskinan apa yang digunakan. Indikator- indikator yang selama ini dipakai antara lain dari BPS, World Bank, Prof.Sayogyo dan lain- lain. 


\section{MIMBAR \\ A GRIBISNIS \\ ISSN 2460-4321}

Volume 1 • Nomor 1 • Juli 2015

Hampir semua pendekatan dalam mengkaji kemiskinan masih berporos pada paradigma modernisasi yang kajiannya didasari oleh teoriteori pertumbuhan ekonomi, human capital, produksi sesuai dengan teori- teori ekonomi neo klasik orthodox (Elson, 1997; Suharto,2001). Sejak ahli ekonomi menemukan pendapatan nasional (GNP) sebagai indikator dalam mengukur tingkat kemakmuran negara pada tahun 1950-an, hingga kini hampir semua ilmu sosial selalu merujuk pada pendekatan tersebut manakala berbicara masalah kemajuan suatu negara atau masyarakat. Pengukuran kemiskinan yang berpijak pada perspektif "kemiskinan pendapatan" yang menggunakan pendapatan sebagai satu- satunya indikator "garis kemiskinan" juga merupakan bukti dari masih kuatnya dominasi model ekonomi neo klasik tersebut.

Indikator GNP sendiri masih memiliki kelemahan dalam memotret kondisi kemajuan dan kemiskinan suatu entitas sosial, sejak tahun 1970-an telah dikembangkan berbagai pendekatan alternatif. Diantaranya adalah kombinasi garis kemiskinan dan distribusi pendapatan yang dikembangkan Sen (1973), Sosial Accounting Matrix (SAM) oleh Pyatt dan Round (1977), Physical Quality Of Life Index (PQLI) yang dikembangkan Morris (1977). (Suharto, 1998).

Pada tahun 1990-an, salah satu lembaga dunia yakni UNDP memperkenalkan pendekatan pembangunan manusia (human development) dalam mengukur kemajuan dan kemiskinan, seperti Human Development Index (HDI) dan Human Poverty Index (HPI). Pendekatan yang digunakan UNDP relatif lebih komprehensif dan mencakup faktor ekonomi, sosial dan budaya kaum miskin. Sebagaimana dikaji oleh Suharto (2002) pendekatan yang digunakan UNDP berporos pada ide- ide heterodox dari paradigma popular development yang memadukan model kebutuhan dasar (basic need model) yang dikembangkan oleh Paul Streeten dan konsep kapabilitas (capability) yang dikembangkan oleh pemenang nobel ekonomi 1998, Amartya Sen.

Dalam merumuskan cara penanggulangan kemiskinan diperlukan pemahaman menyeluruh mengenai kondisi sosial ekonomi masyarakat miskin itu sendiri yang dalam kenyataannya pasti akan berbeda antar satu wilayah dengan wilayah lainnya. Selama ini, perencanaan pembangunan berbasis pertumbuhan seringnya dilakukan secara sentaralistis atau top down tanpa mengindahkan keanekaragaman potensi lokal masing- masing wilayah. Masyarakat miskin dipandang hanya sebagai objek dari pembangunan yang dianggap kondisinya statis dalam menghadapi masalah kemiskinannya. Proses ini memberi hak yang istimewa kepada metodologi dan pengetahuan tertentu tentang kemiskinan dan bersikap eksklusif terhadap yang lain. Hanya para pakar dengan pengetahuan teknis tertentu yang dianggap paham tentang kemiskinan (McGee \& Brock, 2001).

Para pakar terperangkap di dalam pengertian yang sempit tentang kemiskinan. Kemiskinan hanya dilihat dalam bentuk rendahnya pendapatan dan konsumsi yang memungkinkan pendekatan yang rasional tanpa melihat aspek- aspek lain seperti "wellbeing atau illbeing" (Chambers, 2002; Myers, 1999). Kaum miskin tidak memiliki makanan yang cukup untuk konsumsi, atau tempat layak untuk berteduh, atau air bersih yang cukup. Tanah mereka miskin unsur hara, tidak ada air untuk irigasi, jalan- jalan tidak layak, dan tidak ada sekolah untuk anak- anak. Pandangan kemiskinan ini kemudian mendorong perencanaan penyediaan "yang tidak ada": makanan, rumah, sumur, dan lain- lain (Haning,2005).

Penanggulangan kemiskinan yang lainnya berhubungan dengan pengetahuan atau keterampilan yang tidak ada. Orang miskin mungkin tidak mengerti nutrisi, pentingnya mengkonsumsi air bersih dan sehat, pentingnya pengaturan jarak kelahiran, bagaimana membaca instruksi pada pembungkus bibit. Mereka tidak tahu pertanian yang berkelanjutan, bagaimana menjalankan bisnis, pentingnya menabung. Pandangan kemiskinan ini kemudian mendorong lahirnya programprogram peningkatan pengetahuan melalui pendidikan formal dan informal. Diasumsikan bahwa jika si miskin telah cukup belajar, maka dia tidak lagi miskin.

Berdasarkan pada pandangan- pandangan mengenai penyebab dan cara penanggulangan kemiskinan yang telah dijelaskan pada paragrap- paragrap sebelumnya, maka tulisan ini dilakukan untuk memahami persoalan 


\section{Analisis Perbandingan Konsep Keberfungsian Sosial dalam Pengentasan Kemiskinan Nelayan di Wilayah Pesisir}

\section{TINTIN FEBRIANTI}

kemiskinan dengan menggunakan kerangka teori keberfungsian sosial ( sosial functioning) (Siporin, 1975) dengan pendekatan sustainable livelihoods ( Allison \& Ellis, 2001; Allison \& Horemans, 2006 ).

\section{METODE PENELITIAN}

Penelitian ini merupakan hasil analisis dari berbagai kajian literatur terkait kemiskinan dan keberfungsian sosial ( social functioning ). Hasil penelusuran pustaka disajikan secara deskripsi analitis untuk mengetahui perbedaan berbagai paradigma dalam memahami kemiskinan.

\section{HASIL DAN PEMBAHASAN}

Teori- teori kemiskinan pada umumnya bermuara pada dua paradigm besar yang juga berpengaruh pada pemahaman mengenai kemiskinan dan penanggulangan kemiskinan. Dua paradigm yang dimaksud adalah neoliberal dan demokrasi sosial. Dua paradigma ini me:miliki perbedaan yang sangat jelas terutama dalam melihat kemiskinan maupun dalam memberikan solusi penyelesaian masalah kemiskinan. Paradigma yang dimaksud adalah sebagai berikut :

\section{Paradigma Neo - Liberal}

Pada paradigm ini individu dan mekanisme pasar menjadi fokus utama dalam melihat kemiskinan (Syahyuti,2006). Pendekatan ini menempatkan kebebasan individu sebagai komponen penting dalam suatu masyarakat. Oleh karena itu dalam melihat kemiskinan, pendekatan ini memberikan penjelasan bahwa kemiskinan merupakan persoalan individu yang merupakan akibat dari pilihan- pilihan individu. Bagi pendekatan ini kekuatan pasar merupakan kunci utama untuk menyelesaikan masalah kemiskinan. Hal ini dikarenakan kekuatan pasar yang diperluas dan pertumbuhan ekonomi yang tinggi akan menghapuskan kemiskinan (Syahyuti, 2006). Bagi pendekatan ini strategi penanggulangan kemiskinan bersifat sementara dan peran negara sangat minimum. Peran negara baru dilakukan bila institusi- institusi di masyarakat, seperti keluarga, kelompokkelompok swadaya, maupun lembaga- lembaga lainnya tidak mampu lagi menangani kemiskinan.

Paradigma neo liberal ini digerakkan oleh Bank Dunia dan telah menjadi pendekatan yang digunakan oleh hampir semua kajian mengenai kemiskinan. Teori- teori modernisasi yang menekankan pada pertumbuhan ekonomi dan produksi merupakan dasar teori- teori dari paradigm ini (Suharto,2002). Salah satu indikatornya adalah pendapatan nasional (GNP), yang sejak tahun 1950-an mulai dijadikan indikator pembangunan. Para ilmuwan sosial selalu merujuk pada pendekatan ini saat mengkaji masalah kemiskinan suatu negara. Pengukuran kemiskinan kemudian sangat dipengaruhi oleh perspektif income poverty yang menggunakan pendapatan sebagai satu- satunya indikator "garis kemiskinan" (Suharto, 2009).

Kelemahan paradigm ini adalah terlalu memandang kemiskinan hanya melalui pendapatan dan kurang melibatkan orang miskin sebagai subjek dalam permasalahan kemiskinan (Satterthwaite, 1997). Hal ini mengakibatkan bentuk- bentuk kemiskinan yang muncul dalam masyarakat kurang mendapatkan perhatian. Bentuk- bentuk kemiskinan yang tidak dapat ditangkap oleh paradigma ini terutama bentuk kemiskinan yang disebabkan oleh dimensi sosial dalam masyarakat atau kelompok masyarakat. Akibatnya akar permasalahan yang menjadi penyebab kemiskinan juga tidak dapat ditemukan, Namun memang pendekatan income poverty ini lebih mudah dilihat dan dikaji karena langsung dapat terukur, serta sasaran pada perbaikan di tingkat individu langsung dirasakan oleh masyarakat miskin.

2. Paradigma Demokrasi Sosial

Paradigma ini tidak melihat kemiskinan sebagai persoalan individu, melainkan lebih melihatnya sebagai persoalan struktural (Cheyne, O'Brien dan Belgrave, 1998). Ketidakadilan dan ketimpangan dalam masyarakatlah yang mengakibatkan kemiskinan ada dalam masyarakat. Bagi pendekatan ini tertutupnya akses- akses bagi kelompok tertentu menjadi penyebab terjadinya kemiskinan. Pendekatan ini sangat mengkritik sistem pasar bebas, namun tidak memandang sistem kapitalis sebagai sistem yang harus dihapuskan, karena masih dipandang sebagai bentuk pengorganisasian ekonomi yang paling efektif (Cheyne, O’Brien dan Belgrave, 1998).

Pendekatan ini juga menekankan pada kesetaraan sebagai prasyarat penting dalam memperoleh kemandirian dan kebebasan (Syahyuti, 2006). Kemandirian dan kebebasan 


\section{MIMBAR \\ A GRIBISNIS}

ISSN 2460-4321

Volume 1・Nomor 1・Juli 2015

ini akan tercapai jika setiap orang memiliki atau mampu menjangkau sumber- sumber bagi potensi dirinya seperti pendidikan, kesehatan yang baik dan pendapatan yang cukup. Kebebasan di sini bukan sekedar bebas dari pengaruh luar namun bebas pula dalam menentukan pilihan- pilihan. Disinilah peran negara diperlukan untuk bisa memberikan jaminan bagi setiap individu untuk dapat berpartisipasi dalam transaksi- transaksi kemasyarakatan, dimana mereka dimungkinkan untuk menentukan pilihan- pilihannya dan memenuhi kebutuhan- kebutuhannya.

Peran negara dalam pendekatan ini cukup penting terutama dalam merumuskan strategi untuk menanggulangi kemiskinan. Bagi pendekatan ini kemiskinan harus ditangani secara institusional (melembaga), misalnya melalui program jaminan sosial. Salah satu contohnya adalah pemberian tunjangan pendapatan atau dana pensiun, akan dapat meningkatkan kebebasan, hal ini dikarenakan tersedianya penghasilan dasar sehingga orang akan memiliki kemampuan untuk memenuhi kebutuhan dan menentukan pilihan- pilihannya, dan sebaliknya ketiadaan penghasilan dasar tersebut dapat menyebabkan ketergantungan.

Kelemahan teori ini adalah adanya ketergantungan yang tinggi pada negara dalam membetuk struktur dan institusi untuk menanggulangi kemiskinan. Padahal pencapaian pembentukan struktur dan institusi yang tepat dalam menangani kemiskinan itu sendiri tergantung pada kapabilitas kelompok miskin. Penggunaan kemiskinan relatif dalam pendekatan ini juga lebih menyulitkan dalam membentuk kebutuhan standar yang diperlukan oleh kelompok miskin. Hal ini dikarenakan kemiskinan tidak dilihat dari kebutuhan minimal yang harus dicapai tapi lebih pada ratarata kemampuan penduduk dalam memenuhi kebutuhan hidupnya. Namun demikian pendekatan ini membuka dimensi lain dari penyebab kemiskinan yaitu pada struktur dan institusi, yang telah menyebabkan tertutupnya akses bagi kelompok tertentu dalam masyarakat. Sehingga melalui pendekatan ini dapat dilihat bahwa akar permasalahan kemiskinan bukan hanya sekedar pada kemampuan individu tetapi bagaimana struktur dan institusi dalam masyarakat memberikan jaminan bagi semua kelompok untuk mendapatkan kesetaraan dalam mencapai kemandirian dan kebebasan.

Perbedaan kedua paradigm tersebut dalam melihat kemiskinan maupun penyelesaian masalah kemiskinan sangat terlihat, baik dalam merumuskan penyebab maupun memberikan alternatif solusi mengatasi kemiskinan

3. Keberfungsian Sosial

Kedua pendekatan diatas memiliki kelemahan oleh karenanya timbul pendekatan lainnya untuk menutupi kelemahan tersebut, yaitu pendekatan keberfungsian sosial. Pendekatan ketiga ini lebih mengarah pada pendekatan demokrasi sosial. Pendekatan ketiga ini lebih mengarah pada pendekatan demokrasi sosial (Suharto, 2009). Pendekatan ini menekankan pada cara yang dilakukan individu- individu dan kelompok dalam melaksanakan tugas kehidupan untuk memenuhi kebutuhan masyarakatnya. Fokus utama dari pendekatan ini adalah pada kapabilitas individu, keluarga atau masyarakat dalam menjalankan peran- peran sosial di lingkungannya. Salah satunya teori yang mendukung paradigma keberfungsian sosial adalah teori yang dikemukakan oleh Baker, Dubois dan Miley (1992). Teori tersebut menyatakan bahwa keberfungsian sosial berkaitan dengan kemampuan seseorang dalam memenuhi kebutuhan dasar diri dan keluarganya, serta dalam memberikan kontribusi positif bagi masyarakat. Melalui pendekatan ini individu dianggap sebagai subyek dari segenap proses dan aktivitas kehidupannya. Sehingga setiap individu memiliki dan atau dapat menjangkau, memanfaatkan, dan memobilisasi ast dan sumber- sumber yang ada di sekitar dirinya.

Pendekatan ini memandang kelompok miskin bukan sebagai objek yang pasif yang hanya dicirikan oleh kondisi dan karakteristik kemiskinan. Kelompok miskin bagi pendekatan ini adalah individu yang memiliki seperangkat pengetahuan dan keterampilan yang sering digunakannya dalam mengatasi berbagai permasalahan seputar kemiskinannya. Keberfungsian sosial dapat menggambarkan karakteristik dan dinamika kemiskinan yang lebih realistis dan komprehensif. Melalui pendekatan ini dapat dijelaskan bagaimana keluarga miskin merespon dan mengatasi permasalahan sosial ekonomi yang terkait 


\section{TINTIN FEBRIANTI}

dengan situasi kemiskinannya. Serta bagaimana struktur rumah tangga, keluarga, kekerabatan, dan jaringan sosial mempengaruhi kehidupan orang miskin. Pendekatan ini lebih menekankan pada apa yang dimiliki si miskin dan bukan pada apa yang tidak dimiliki si miskin.

Untuk mempelajari kemiskinan, pendekatan keberfungsian sosial menekankan pada empat poin yaitu (Suharto, 2009) :

1. Kemiskinan sebaiknya dilihat secara dinamis yang menyangkut usaha dan kemampuan si miskin dalam kemiskinannya. Pada poin pertama ini juga termasuk efektivitas jaringan sosial dalam menjalankan fungsi sosialnya, dimana jaringan sosial yang dimaksud termasuk pula kelembagaan kemasyarakatan dan programprogram anti kemiskinan setempat.

2. Menggunakan indikator komposit untuk mengukur kemiskinan, dengan unit analisis keluarga atau rumah tangga dan jaringan sosial yang ada di sekitarnya

3. Lebih menekankan pada konsep kemampuan sosial daripada hanya pada konsep pendapatan dalam memotret kondisi sekaligus dinamika kemiskinan

4. Kemampuan sosial keluarga miskin difokuskan pada beberapa indikator kunci, yang mencakup kemampuan kemampuan keluarga miskin dalam memperoleh mata pencaharian (livelihood capabilities), memenuhi kebutuhan dasar (basic needs fulfillment), mengelola aset (aset management), menjangkau sumber- sumber (access to resources), berpartisipasi dalam kegiatan kemasyarakatan (access to sosial capital) serta kemampuan dalam menghadapi goncangan dan tekanan (cope with shocks and stress). Sedangkan indikator kunci untuk mengukur jaringan sosial mencakup kemampuan lembaga- lembaga sosial memperoleh sumber daya (SDM dan finansial), menjalankan peran atau fungsi utamanya, mengelola aset, menjangkau sumber, berpartisipasi dalam program anti kemiskinan, dan peran dalam menghadapi goncangan dan tekanan sosial.

Paradigma ini lebih lengkap dibandingkan dua paradigma sebelumnya karena selain menekankan pada institusi, paradigma ini juga tidak melupakan kemampuan individu dalam mengatasi masalah kemiskinannya. Pada paradigma ini kelompok miskin tidak dianggap pasif namun dianggap memiliki kemampuan dan potensi dalam mengatasi kemiskinannya, dibantu dengan kemampuan dan potensi dalam mengatasi kemiskinannya, dibantu dengan kemampuan jaringan sosial yang ada dalam masyarakat. Gabungan kemampuan institusi dan individu ini akan membuat kajian mengenai kemiskinan yang dialami suatu kelompok menjadi lebih lengkap.

\section{PENUTUP}

Pendekatan dalam memahami kemiskinan seyogyanya dilakukan dengan mempertimbangkan semua aspek yang dimiliki oleh orang miskin sehingga berbagai program pengentasn kemiskinan tidak sekedar membagibagikan berbagai sarana prasarana yang tidak dimiliki oleh orang miskin melainkan idealnya lebih memperkuat berbagai aset atau sumberdaya baik finansial, fisik, sosial juga keluarga yang digunakan orang miskin untuk mempertahankan kehidupannya dengan tidak selalu menggantungkan nasibnya pada pihak luar ataupun intervensi pemerintah.

\section{DAFTAR PUSTAKA}

Allison, Edward H and Benoit Horemans. 2006. Putting The Principles Of The Sustainable Livelihoods Approach Into Fisheries Development Policy and Practice. Marine Policy 30 (2006) 757-766

Allison, Edward H And Frank Ellis. 2001. The Livelihoods Approach and Management Of Small Scale Fisheries. Marine Policy 25 (2001) 377-388.

Badan Pusat Statistik. 2009. PDRB Menurut Lapangan Usaha 2008. BPS Kabupaten Ciamis. Ciamis.

Bene, Christophe. 2003. When Fishery Rhymes With Poverty: A First Step Beyond The Old Paradigm On Poverty In Small Scale Fisheries. World Development Vol.31 No.6 p.949 - 2003

Bene, Christophe. 2011. Poverty In Small Scale Fisheries. Old Issue New Analysis. Progress In Development Studies 11, 2 (2011)

BPS Jawa Barat. 2014. Berita Resmi Statistik. Tingkat Kemiskinan Jawa Barat September 2013.

Bennet, H.W. 1978. The Ecological Transition. Cultural and Human Adaptation. New York. Pargamnon Press Inc. 


\section{MIMBAR \\ A GRIBISNIS \\ ISSN 2460-4321}

Volume 1 • Nomor 1 • Juli 2015

Bosshard,A. 2000. A Methodology And Terminology Of Sustaibability Assessment And Its Perpectives For Rural Planning Agriculture, Ecosystem And Environment 77 pp 29- 41

Dahuri, Rokhmin. 2001. Paradigma Baru Pembangunan Indonesia Berbasis Kelautan, Orasi Ilmiah Guru Besar. IPB. Bogor

Dinas Perikanan dan Kelautan Propinsi Jawa Timur. 2006. Perikanan Jawa Timur Dalam Angka Tahun 2005. Surabaya

Djojohadikusumo, S. 1994. Dasar Teori Ekonomi Pertumbuhan dan Ekonomi Pembangunan. LP3ES. Pustaka. Jakarta. Andalas University Press. Padang

Elfindri. 2002. Ekonomi Patron - Client.

Ensiklopedia Indonesia. 1990. Jakarta. PT Ichtiar Baru Van Hoeve Loagman

Fauzi, A. 2004. Ekonomi Sumberdaya Alam dan Lingkungan, Teori dan Aplikasi. Gramedia Pustaka, Jakarta.

Greend, D.J. and I. Szabalcs. 1992. Soil Resilience and Sustainable Land Use. In Proceedings of a Sysposium Held in Budafest. 28 September to 2 Oktober 1992. Including the Second Workshop on the Ecological Foundations of Sustainable Agriculture (WEFSA II). Research Institute for Soil Science and Agricultural Chemistry Hungarian Academy of Sciences. Budafest.

Greenland, Dj. and Szabolcs. 1994. Soil Resilience and Sustainable Land Use. Short Run Press Ltd. UK

Hanley, N. M. 2001. Modelling Sustainable Development: System Dynamic and Inputoutput Aproaches. Department of Economic University of Glasgow. Scotland.

Hidayat, Syarif dan Darwin Syamsulbahri. 2001. Pemberdayaan Ekonomi Rakyat. PT Pustaka Quantum. Jakarta.

KMNLH dan UNDP. 2000. Membuat Pembangunan Berkelanjutan. Kantor Menteri Negara Lingkungan Hidup. Jakarta.

Leach, M.R. and I. Scoones. 1997. Challenges To Community-Based Sustainable Development. Dynamics, Entitlements, Institutions. IDS Bull. 28(4): 414
Marten, G. G. 2001. Human Ecology. Basic Concepts for Sustainable Development. London.

Madrie. 1986. Beberapa Faktor Yang Berkelanjutan Dengan Partisipasi Masyarakat Desa dalam Pembangunan Pedesaan. IPB. Bogor.

Meyer M. F. and J.R.E. Harger. 1996. Definition of Indicators for Environmentally Sustainable Development. Unesco - 10C. Lrue Miollis. Paris. France.

Mitchell, B. $1997 . \quad$ Resource and Environmental Management. University of Waterlo. Waterlo. Ontario.

Mubyarto. 1988. Partisipasi Masyarakat Dalam Pembangunan Pedesaan. Liberty. Yogyakarta

Mubyarto. 2002. Membangkitkan ekonomi kerakyatan melalui gerakan koperasi: Peran Perguruan Tinggi. Jurnal Ekonomi Rakyat Tahun I No. 6 Agustus. 2002.

Natawidjaja, Ronnie S. 2013. Rural Transformation And Poverty. Disampaikan dalam Seminar Nasional Agribisnis. Laboratorium Sosial Ekonomi Fakultas Pertanian Universitas Padjajaran.

Nikijuluw, Victor.P.H. 2001. Aspek Sosial Ekonomi Masyarakat Pesisir dan Strategi Pemberdayaan Mereka

P. Hadi, Sudharto. 1999. Peran Serta Masyarakat dan Keterbukaan Informasi Dalam Proses AMDAL. Disampaikan pada Seminar Partisipasi Masyarakat dan Keterbukaan Informasi dalam Proses AMDAL. BAPEDAL. Jakarta.

Plessis, C. D. 1999. Sustainable Development Demands Dialoque Between Develope And Developing Worlds. J. Building Research \& Information 27(6),pp 378-389.

Ritzer, G dan Douglas J. Goodman. 2007. Teori Sosiologi Modern, Edisi Ke-6. Terjemahan Alimandan, Jakarta. Kencana Prenada Media Group.

Robin, M.L. and L.S. Mearns. 1997. Editorial: Community Based Sustainable Development. Consensus or Conflict? IDS Bull. 28(4).

Roderic, G. and T. Meppem. 1997. Planning for Sustainability as a Learning Concept. New England Ecological Economic Group. Centre for Water Policy Research. 


\section{TINTIN FEBRIANTI}

University of New England. Armidale. Australia.

Sitorus, S. 2004. Pengembangan Sumber Daya Berkelanjutan. Laboratorium Perencanaan Pengembangan Sumber Daya Lahan IPB. Bogor.

Slamet,S. 1985. Meningkatkan Partisipasi Masyarakat Dalam Pembangunan Pedesaan. Interaksi Nomor 1Tahun I. Jakarta.

Soemarwoto, O. 2001. Ekologi Lingkungan Hidup dan Pembangunan. Djambatan.. Jakarta

Sudharto. 1999. Peran Serta Masyarakat dan Keterbukaan Informasi Dalam Proses AMDAL. Disampaikan pada Seminar Partisipasi Masyarakat dan Keterbukaan Informasi dalam Proses AMDAL. BAPEDAL. Jakarta.

Suharto, Edi. 2002. Coping Strategies Dan Keberfungsian Sosial Mengembangkan Pendekatan Pekerjaan Sosial Dalam Mengkaji Dan Menangani Kemiskinan. Makalah disampaikan pada Seminar "Kemiskinan dan Keberfungsian Sosial:Merancang Kembangkan Program Pembangunan Kesejahteraan Sosial Yang Bernuansa Pekerjaan Sosial". 17 Desember 2002. Institut Pertanian Bogor.

Sumodiningrat G. $1999 . \quad$ Pemberdayaan ekonomi rakyat: Mempertajam upaya pemulihan ekonomi. Pengembangan Perbankan

Tain, Anas. 2010. Analisis Kemiskinan dan Adaptasi Rumah Tangga Nelayan Motor Tempel Di Wilayah Tangkap Lebih Jawa Timur. Universitas Padjajaran. Bandung.

Thohir, Mudjahirin. 1999. Wacana Masyarakat dan Kebudayaan Jawa Pesisiran. Penerbit Bendera. Semarang.

Todaro, Michael P. 1998. Pembangunan Ekonomi Di Dunia Ketiga. Penerbit Erlangga. Jakarta.

Tuwo, Ambo. 2011. Pengelolaan Ekowisata Pesisir dan Laut Pendekatan Ekologi, Sosial Ekonomi, Kelembagaan dan Sarana Wilayah. Brilian Internasional. Surabaya.

Wardoyo. 1992. Pendekatan Penyuluhan Pertanian Untuk Meningkatkan Partisipasi Masyarakat Dalam Penyuluhan Pembangunan di Indonesia Menyongsong Abad XXI. Editor Pustaka Pembangunan Swadaya Nusantara. Jakarta.
Wibowo, Rimun.Program Partisipasi Pembangunan Masyarakat Desa Dalam Pembangunan Sektor Lingkungan. Makalah disampaikan Pada Acara Pelatihan Pengelolaan Lingkungan Hidup Dengan

World Bank. 2014. Laporan Perkembangan Triwulanan Perekonomian Indonesia 2013. 


\section{MIMBAR Agribisnis ISSN 2460-432I \\ Volume 1・Nomor 1 • Juli 2015}

